Historia Slavorum Occidentis

2021, nr 4 (31)

ISSN 2084-1213

DOI: $10.15804 /$ hso210402

ZdzisŁaw Pentek (Poznań)

ORCID: 0000-0001-6500-6559

\title{
Karantanie - Słowianie alpejscy od VI do XV w.*
}

Keywords: Carantania, the Slavs, history

Słowa kluczowe: Karantania, Słowianie, historia

Abstract: It is an outline of the history of Carantania and Slavic tribes from the $7^{\text {th }}-14^{\text {th }}$ centuries. The author drew attention to Carantan's baptism, assimilation processes and their material culture.

Współczesna Słowenia licząca nieco ponad 20 tys. $\mathrm{km}^{2}$ tylko w niewielkiej części odpowiada terytorium, które historycznie zasiedlały plemiona słowiańskie od końca VI w. Warto prześledzić historię tej grupy Słowian, ulokowanych u podnóża Alp, $\mathrm{z}$ racji współzawodnictwa $\mathrm{z}$ ludem Bawarów i narzucenia politycznej dominacji ze strony Franków, jak również z faktu przyjęcia chrześcijaństwa, co miało skutki długofalowe dla Karantan.

Historiografia stosuje wymienne nazwy na tytułowe plemiona słowiańskie - Karantanie, Chorutanie, Słowianie alpejscy - wreszcie formę współczesną - Słoweńcy, choć nie jest ona najwłaściwsza dla okresu początkowego ${ }^{1}$.

* Tekst powstał w ramach realizacji grantu NCN 11 H 1202 1681, Historia i kultura dawnych Stowian.

1 Podstawową syntezą historii Karantan jest praca B. Grafenauer, Zgodovina slovenskega naroda, t. 1-3, Ljubljana 1954-1961, zwłaszcza t. 1-2. Niewątpliwą wadą publikacji jest brak odniesień do źródeł. Praca ta jest oparta na wypisach źródłowych o Karantanach za lata 500- 
Rzymianie i ich dziejopisarstwo określili ten lud jako Carni. Byli oni pochodzenia celtyckiego lub retyckiego, a w czasach rzymskich zamieszkiwali ziemie tzw. Alp Karnijskich. W VIII w. nadal funkcjonował ten termin w postaci Carantanus i dalej ewoluowal na przestrzeni IX-XII w. ${ }^{2}$ Termin Karantanie ostatecznie został przypisany ludom słowiańskim, które napływały na terytoria Alp Karnijskich od końca VI, w VII i VIII w. Około początku VIII w. musiało dojść do bardziej dynamicznych przeobrażeń na tych ziemiach, gdyż pojawiają się wskazówki źródłowe to poświadczające. Wpierw Paweł Diakon (725-730-800) przywołuje termin Karantanum³ Następnie Anonim z Rawenny (VII/VIII w.) użył określenia Carontani w odniesieniu do mieszkających tam ludów ${ }^{4}$. W tym przypadku mamy do czynienia ze Słowianami, którzy zjawili się tu z zamiarem osiedlenia się na terytorium pomiędzy rzekami Mura i Drawa. Jednak etnogeneza słowiańskich Karantan nie jest do końca jasna, podobnie jak wszystkich Słowian południowych.

-1246, którą przygotowali Franc Kos (1853-1924) i jego syn, Milko Kos (1892-1972) w pięciu tomach: Gradivo za zgodovino Slovencev v srednjem veku, zbral Franc Kos (tomy I-IV) i Peta kniga uredil Milko Kos, Ljubjana 1902-1928. O przeszłości Wielkiej Karantanii zob. też Karantanien und der Alpen-Adria-Raum im Frühmittelalter, hrsg. G. Hödl, J. Grabmayer, Wien 1993; H.D. Kahl, Der Staat der Karantanen. Fakten, Thesen und Fragen zu einer frühen slawischen Machtbildung im Ostalpenraum (7.-9. Jh.), Ljubljana 2002. O etymologii nazwy zob. F. Bezlaj, Etimološki slovar slovenskega jezika, Vol. 2: K-O, red. B. Gerlanc, Ljubljana 1982, s. 68; P. Štih, Regnum Carantanum, Zgodovinski časopis letnik 40 (1986), št. 3, s. 215-231; J. Skowronek, M. Tanty, T. Wasilewski, Historia Stowian potudniowych i zachodnich, Warszawa 1988, s. 24; D.J. Ovsec, Slovanska mitologija in verovanje, Ljubljana 1991; R. Bratož, Slovenija in sosednje dežele med antiko in karolinško dobo, začetki slovenske etnogeneze, Ljubljana 2000; P. Gleirscher, Karantanien - das slawische Kärnten, Klagenfurt 2000; H.D. Kahl, Der Staat; Karantanien - Mutter von Kärnten und Steiermark, hrsg. W.R. Baier, Hermagoras, Klagenfurt 2003; P. Štih, Glossen zu einer neuen Monographie über Karantanien, Carinthia (2006), s. 99-126; tenże, Karantanci - zgodnjesrednjeveško ljudstvo med Vzhodom in Zahodom, Zgodovinski časopis 61 (2007), s. 47-58; E. Mühle, Die Slawen, München 2017; idem, Die Slawen im Mittelalter zwischen Idee und Wirklichkeit, Köln 2020.

2 B. Grafenauer, Zgodovina, t. 1, s. 83-143; J. Nalepa, Bawaria, SSS, I, s. 95-97; J. Kuryłowicz, Karyntia, SSS, t. II, s. 381; W. Swoboda, Stowianie w Alpach, SSS, V, s. 285-288; J. Strzelczyk, Iroszkoci w kulturze średniowiecznej Europy, Warszawa 1987, s. 219-224; na mapach Guido z Pisy (zm. 1169) termin Karentania, J. Strzelczyk, Mapy, SSS III, s. 164; P. Štih, Ozemlje Slovenije v zgodnjem srednjem veku, osnovne poteze zgodovinskega razvoja od začetka 6 . stoletja do konca 9. stoletja, Ljubljana 2001.

3 Paweł Diakon, Historia Longobardów, przełożyl, wstępem i komentarzem opatrzył Ignacy Lewandowski, Warszawa 1995, s. 294.

4 Itineraria Romana, Bd. II: Ravennatis Anonymi cosmographia et Guidonis geographica, ed. J. Schnetz, Leipzig 1929 i nowe wydanie 1990. 
Słowianie w końcu VI w. przybywszy z kierunków wschodnich lub/i północno-wschodnich zaczęli przeciwstawiać się Bawarom nad górnym biegiem Drawy około lat 593-595, co poświadcza ich chęć migracji na nowe tereny. W 610 r. Słowianie będący wtedy w sojuszu z Awarami rozbili pod Aguntum księcia Bawarów Garibalda II (585-625) . Było to jednak pyrrusowe zwycięstwo, ponieważ Bawarzy odbili łupy zagarnięte przez Słowian i wypędzili ich ze swych ziem ${ }^{6}$.

Prawdopodobnie Słowianie żyjący w dolinach Alp Julijskich przesuwali się na wschód Równiny Friulskiej, ale te grupy zostały na początku VII w. powstrzymane przez dwie przeszkody. Jedną była granica Cesarstwa Bizantyńskiego w Istrii, drugą natomiast tzw. limes Longobardorum. Być może dlatego dalsza ekspansja została skierowana ku zachodowi i po kolejnych walkach z Bawarami, Słowianie w $628 \mathrm{r}$. opanowali górny bieg Drawy. Była to najbardziej na zachód wysunięta grupa plemion słowiańskich. Słowianie ci zatrzymali się jednak w pochodzie na zachód, z powodu niemożności dalszego przezwyciężenia plemion bawarskich, i prawie równocześnie odpierali ataki Longobardów (625 r.). To zaś wpłynęło na powolne zarzucanie koczownictwa i przechodzenia na osiadły tryb życia. Na historię polityczną Karantan wpływ miało rozerwanie sojuszu awarsko-słowiańskiego po nieudanym oblężeniu Konstantynopola w 626 r. $^{7}$

Wówczas na arenie dziejowej ukazała się postać określanego mianem księcia karantańskiego Waluka (Waltunc) $)^{8}$. Utworzył on zapewne księstwo, czerpiąc wzorce od Bawarów. Wiadomo tyle, że stolica miała znajdować się w okolicach Klagenfurtu, w Karnburgu. Jednakże ciągłe zagrożenie awarskie skłoniło Waluka do przystąpienia do tzw. państwa Samona (Zamo) pod nazwą Marcha Vindorum. Stać się to mogło około połowy VII w. Kiedy zaś związek Samona uległ rozpadowi (lata 658-661), Karantanie wyodrębnili swój byt polityczny, tym samym umacniając wewnętrzny rozwój przez niezawisłość od elementów zewnętrznych i obcych sobie. Tereny wówczas zajmowane przez Karantan, czyli w okresie VII-IX w., to: Karyntia oraz Dolna i Górna Styria. Należy pamiętać o obszarze południowym zajmowanym przez Słowian alpejskich, czyli o grodzie Kranja (Carniola), późniejszej Lubljanie.

5 Paweł Diakon, Historia Longobardów, s. 276.

6 Tamże.

7 M. Hurbanič, The Avar Siege of Constantinople in 626: History and Legend, [London-New York] 2019, s. 123 n.

8 W. Swoboda, Walluk, SSS, VI, s. 300-301; P. Korošec, Alpski Slovani, Ljubljana 1990, s. 17. Nie zostało wyjaśnione, czy był on księciem karynckiego związku plemiennego, czy też księciem wielkoplemiennym. 
Luki źródłowe nie pozwalają właściwie nic powiedzieć o kolejnych dziesięcioleciach księstwa Karantan, aż do lat czterdziestych VIII w. Jeśli ponownie w VIII w. pojawiają się Karantanie w źródłach, znaczy to tyle, że Waluk lub inny możny karantański założyli dynastię, nawiązując do tradycji dziedziczenia władzy w obrębie własnego rodu. Niewątpliwie, kontakty Karantan z Bawarami - w pierwszej połowie VIII w. - nie sprowadzały się tylko do wzajemnych walk, lecz umożliwiły podpatrywanie i przejmowanie zwyczajów, zasad funkcjonowania własnego terytorium. W latach czterdziestych VIII w., Bawarzy podporządkowali się (743) politycznie Frankom. Miało to ścisły związek przyczynowy z nową ekspansją Awarów, która wywarła polityczną presję na księcia Karantan - Boruta ${ }^{9}$ (zm. 749). Ten, szukając sprzymierzeńców do walki z najeźdźcą, opowiedział się za sojuszem z Bawarami, jednocześnie wspierając wojska frankijskie. Borut, nie mogąc się oprzeć zewnętrznemu niebezpieczeństwu, podporządkował się polityczne Frankom, a bezpośrednio Bawarom w roku $745^{10}$. Ci zaś zostali wprowadzeni w świat chrześcijański przez Franków już wcześniej na początku VIII w., zresztą w podobnych okolicznościach zagrożenia awarskiego. Ta zmiana usadowienia politycznego Karantan oznaczała dla nich powolną akomodację frankijskiego systemu feudalnego. Tak nakłada się historia przyjęcia chrztu przez Karantan z ich historią polityczną ${ }^{11}$.

Ustrój księstwa nie uległ jednak diametralnej zmianie. Karantanie zachowali prawo wyboru księcia oraz zarządzania państwem. Jednak chrystianizacja nie tylko wpłynęła na powstrzymanie agresji awarskiej, lecz także przyczyniła się do związania Karantan umowami, które wymusiły na władcy kroki mające być zabezpieczeniem jego intencji. Na dowód swych zamiarów Borut wysłał do Bawarów swego bratanka Chotimira (Hotimir) ${ }^{12}$ i stryjecznego brata Kakacjusza-Gorazda ${ }^{13}$. Można ich uważać za zakładników w trakcie przyjmowania chrztu przez pozostałych Karantan. Chotimir i Kakacjusz-Gorazd zostali ochrzczeni, czym dopełniało się zobowiązanie

9 V. Frančić, Boruta, SSS, I, s. 151; H. Wolfram, Salzburg, Bayern, Österreich. Die Conversio Bagoariorum et Carantanorum und die Quellen ihrer Zeit, Wien-München 1995, s. 46.

$10 \mathrm{H}$. Wolfram, Karantanija med vzhodom in zahodom. Obri, Bavarci in Langobardi $v 8$. in 9. stoletju, Zgodvinski Casopis 45 (1991), s. 177-187.

11 H.D. Kahl, Das Fürstentum Karantanien und die Anfänge seiner Christianisierung, [w:] Karantanien und der Alpen, s. 37-99; Z. Pentek, Chrystianizacja Stowian Potudniowych, [w:] Chrystianizacja „Młodszej Europy”, red. J. Dobosz, J. Strzelczyk, M. Matla, Poznań 2016, s. $137-146$.

12 G. Labuda, Chotimir, SSS, I, s. 257-258.

13 Idem, Kakacjusz, SSS, II, s. 351-352. 
Karantan, którzy znaleźli się w nowej sytuacji religijnej. Po śmierci Boruta w 749 r. tron objął Kakacjusz-Gorazd (749-751), który został zaakceptowany przez Franków. Tym samym państwo słowiańskie znalazło się w stanie „półwasalnym” w stosunku do Franków. Po rychłej śmierci Kakacjusza-Gorazda, tron przejął Chotimir (752-769).

Krótki czas pomiędzy przyjęciem chrztu i objęciem rządów przez Chotimira nie pozwolił jeszcze na rozwinięcie akcji misyjnej na terenie Karantanii. Z pobytu u Bawarów, Chotimir powrócił wspólnie z duchownym o imieniu Majoran, aby budować struktury kościelne w Karantanii ${ }^{14}$. Książę podporządkował Kościół arcybiskupstwu w Salzburgu (iryjski biskup Wergiliusz, zm. 784) około 756 r. i powoli rozwijała się akcja misyjna ${ }^{15}$.

Jednak przyjmowanie chrześcijaństwa napotykało opory jeszcze za życia Chotimira. Pierwszy bunt przeciwko nowej religii miał miejsce w latach 763-765, drugi zaś w latach 769-772. Pierwszy zbiegł się ze śmiercią biskupa misyjnego Modesta w 763 r., drugi natomiast ze śmiercią w 768 r. króla Franków, Pepina III Krótkiego. Z tego powodu wybuchł bunt w Bawarii pod wodzą księcia Tasilla III (748-788) wymierzony we Franków, ale nie w chrześcijaństwo ${ }^{16}$. Bunty kierowane były przez możnych karantańskich obawiających się o swe dobra nękane nowymi obciążeniami na rzecz rodzącej się struktury kościelnej ${ }^{17}$. Natomiast uboższe warstwy Karantan, a wśród nich jeńcy i więźniowie, były zainteresowane rozwojem chrześcijaństwa, co potwierdzało dotychczasową regułę. Dowodem niezadowolenia wobec duchowieństwa było jego usunięcie w latach 768-772 z Karantanii. Jednak wsparcie Tassila III okazane nowemu księciu karantańskiemu, Waltunkowi ${ }^{18}$ (772-784), pociągnęło za sobą opanowanie Karantanii przez Bawarów w 772 r. i ustąpienie środowisk antychrześcijańskich. Nie wiadomo jednak, czy Waltunk był synem Chotimira lub wywodził się z rodu Boruta, czy był podesłanym przez Bawa-

14 Z. Čepič et al., Zgodovina Slovencev, Ljubljana 1979, s. 123; J. Strzelczyk, Iroszkoci, s. $224-$ -228 .

15 V. Habijan, Mejniki slovenske zgodovine, Ljubljana 1997, s. 21.

16 J. Leśny, Tassilo III, SSS, VI, s. 33; W. Störmer, Tassilo III, Mittelalterische Lexikon, t. IV, col. 485-486.

17 H. Dopsch, Das Erzbistum Salzburg und der Alpen-Adria-Raum im Frühmittelalter unter besonderer Berücksichtigung des Salzburger Slawenmission, [w: Karantanien und der Alpen, s. 101-150.

18 W. Swoboda, Waltunk, SSS, VI, s. 303; J. Strzelczyk, Iroszkoci, s. 223; H. Wolfram, Karantanija, s. 177-187. 
rów władcą. W to ostatnie wątpią słoweńscy historycy z racji ówczesnego osłabienia Bawarii ${ }^{19}$. W każdym razie w $772 \mathrm{r}$. Waltunk zdusił ostatnich buntowników i przystąpił do odnawiania kultu chrześcijańskiego.

Za akcją szerzenia chrześcijaństwa, ufundowania klasztorów benedyktyńskich w Innichen (769) i Kremsmünster (777) krył się również podtekst politycznej kontroli karantańskich Słowian, gdyż opactwa wzniesiono na pograniczu bawarsko-słowiańskim $^{20}$. Sytuacja uległa także zmianie w państwie Franków, gdzie pierwszoplanową rolę zaczynał odgrywać Karol Wielki. Zneutralizował on w 788 r. Tassila III, skazując go na śmierć w Ingelheim, lecz później ułaskawiając i osadzając dożywotnio w klasztorze Lorch. Karol Wielki przejął wówczas bezpośredni nadzór nad Karantanią. Wreszcie w 803 r. pokonał Awarów, co przełożyło się na utworzenie Marchii Wschodniej i rozszerzanie penetracji frankijskiej w kierunku wschodnim. Wówczas Karantanie byli postrzegani jako ludność drugiej kategorii ze względu na swój status określony przez Karola Wielkiego. Ale frankijska dominacja - a w ślad za nią kolonizacja - wpłynęły na poprawę losu ludności zależnej (m.in. położenie kmieci w nowych wsiach $)^{21}$. O następcach Waltunka wiemy tylko, że panowali w latach 796-828; byli to Pribislav 22 (przed 800 r.), Semik (początek IX w.), Stojmir i Etgar (ok. 811-828) ${ }^{23}$.

W następnych latach po ustąpieniu żywiołu awarskiego rozszerzyło się osadnictwo słowiańskie w kierunku Jeziora Błotnego, czyli Balatonu, co zaznaczyło się w nazewnictwie Dolnej Panonii, którą zaczęto w źródłach określać w 819 r. jako Carantanorum regio. Stało się tak, gdyż około 820 r. Frankowie zatrzymali rodzący się słowiański feudalizm, tworząc z Karantanii hrabstwo. W odpowiedzi na te działania Franków niszczące porządki słowiańskie również Karantanie opowiedzieli się za Ljudevitem ${ }^{24}$, władcą posawskim, przeciwstawiającym się ekspansji margrafów frankijskich. Powstanie Ljudevita (819-822) stało się okazją do wspólnego frontu Słowian z Krainy, Dolnej Panonii, Timoczan i Karantan. Ale powstanie przeciw Frankom okazało się daremne. Ljudevita zabito w 823 r., a zwycięzcy umocnili wła-

19 M. Kos, Zgodovina Slovencev od naselitve do reformacije, Ljubljana 1933, s. 60; J. Strzelczyk, Od Prastowian do Polaków, Kraków 1987, s. 42.

20 M. Kos, Conversio Bagoariorum et Carantanorum, Ljubljana 1936; B. Grafenauer, Zgodovina, t. 1, s. 151-164.

21 T. Wasilewski, Feudalizm $w$ Stowenii, SSS, II, s. 48-49.

22 H. Wolfram, Karantanija, s. 181.

23 Tamże, s. 184-185.

24 B. Grafenauer, Zgodovina, t. 1, s. 171 n.; W. Kowalenko, Ljudevit, SSS, III, s. 85-86. 
dzę nad Karantanią i Krainą. Efekt powstania Ljudevita przyniósł utwierdzenie dotychczasowych stosunków politycznych i przemeblowanie kwestii gospodarczych. Po pierwsze, definitywnie usunięto w Karantanii rodzimą dynastię i zastąpiono ją nową wartością w postaci frankijskich komesów. Po drugie, wprowadzano frankijskie prawo, gospodarkę dominialną, narzucono Słowianom rentę feudalną w postaci robocizny (tlaka) oraz innych powinności na rzecz Franków. To musiało wywrzeć wpływ na zmianę warunków egzystencji oraz ograniczenia w samodzielnym dotąd rozwoju słowiańskiej kultury ${ }^{25}$. Z wolna następować zaczęły procesy germanizacyjne idące $\mathrm{w}$ parze $\mathrm{z}$ dalszymi postępami w chrystianizacji tych obszarów. Było to być może związane z objęciem rządów przez bawarskiego hrabiego Helmwina po śmierci Etgara około 828 r. ${ }^{26}$ Wówczas doszło do powstania komitatów uzależnionych od Marchii Wschodniej, które cementowały nowe porządki i miały zaprowadzić inną strukturę wewnętrzną chroniącą przed najazdami bułgarskimi ${ }^{27}$. Były to komitaty Krainy, Karantanii oraz Dolnej Panonii, które zostały później nadane księciu Pribinie (Privin) ${ }^{28}$ (847-860 lub 861), dotąd władcy księstwa nitrzańskiego. Znalazł on poparcie u Ludwika Niemca i w 848 r. Pribina stał się panem Karantanii. Jego następcą był syn Kocel $^{29}$ (861-874 lub 876); wszedł on w polityczną zależność od księcia wielkomorawskiego Rościsława, którą pod koniec panowania porzucił na rzecz Franków wschodnich.

Kocel utwierdzał chrześcijaństwo, nie tylko wznosząc nowe świątynie, lecz także interesując się misją cyrylo-metodejską od 867 r. oraz dokładając starań do fundacji szkoły przykościelnej w stołecznym Blatnogradzie (obecnie węgierska wieś Zalavár). Popierał on także liturgię w języku słowiańskim, widząc w tym być może czynnik kultywujący rodzimy język, a tym samym hamujący przed dalszym postępem obcych wplywów.

Tekstem źródłowym, który rzuca sporo światła na te i wcześniejsze wydarzenia dotyczące chrztu oraz początków Karantan, jest „Conversio Bagoariorum et Caran-

\footnotetext{
25 B. Grafenauer, Zgodovina, t. 1, s. 164-171; T. Wasilewski, Feudalizm, s. 48-50.

26 Tu warto dodać, że następcami Helmwina zostali kolejno Albar i Pabo; H. Wolfram, Karantanija, s. 184-185.

27 B. Grafenauer, Zgodovina, t. 2, s. 5-10.

28 Tamże, t. 2, s. 41-44; J. Sieklicki, Pribina, SSS, IV, s. 346-347; H. Wolfram, Privina, Fürst in Pannonien (830/40/† um 860), Lexikon des Mittelalters, Bd. 7. München 1995, s. 232.

29 T. Lehr-Spławiński, Kocelj, SSS, II, s. 435; W. Chrzanowski, Świętopełk I Wielki król wielkomorawski (ok. 844-894), Kraków 2008, s. 28, 153.
} 
tanorum” pochodzący właśnie z czasów rządów Kocela z 870 lub 871 r. ${ }^{30}$ Najazdy węgierskie, które rozpoczęły się pod koniec IX w., przyczyniły się do połączenia w jeden organizm ziem karantańskich z Bawarią. Celem tego zabiegu była obrona przed Węgrami, którzy odpychali osadników słowiańskich z okolic Balatonu ${ }^{31}$. W $907 \mathrm{r}$. Węgrzy odnieśli zwycięstwo pod Bratysławą nad koalicją bawarsko-karantańską i odtąd plądrowali tereny Niemiec, kierując się przez Kotlinę Lubljańską. Tym samym jedynie Karantanie utracili tereny nad Balatonem i wycofali się na ziemie, które zajmowali niegdyś. Wpłynęło to na zahamowanie ekspansji Słowian na wschód, jednak nie osłabiło poczucia własnej tożsamości. Dopiero odniesione przez Ottona I zwycięstwo nad Węgrami nad rzeką Lech w 955 r. umożliwiło ekspansję Bawarów.

Jednak w 976 r. Karantania została oddzielona od Bawarii na mocy cesarskiego rozporządzenia. To pozwoliło na budowę nowego organizmu zwanego w historiografii Wielką Karantanią. Tworzyły ją marchie: Karyntia położna nad średnim biegiem rzeki Mury (w późniejszym okresie - Górna Styria), podrawska ze stolicą w Ptuju, sawińska (później zwana Styrią Dolną) w dorzeczu Sawinji oraz kraińska, friulska, istryjska, a także werońska. Jednak niezależność poszczególnych władców marchijskich okazała się słabością w zderzeniu z książętami karantyńskimi, którzy byli uzależnieni od rządów królów niemieckich. Ci zaś traktowali książąt karantańskich jak swoich urzędników, automatycznie nie dopuszczając do tworzenia się nowych struktur dynastycznych. To osłabianie słowiańskich władców odbywało się także przez powierzanie dochodowych terenów rozmaitym rodzinom feudalnym spoza kręgu słowiańskiego lub ośrodkom monastycznym.

Taka praktyka przyczyniła się do osłabienia Karantanii, a w efekcie jej rozpadu w 1035 r. Była to konsekwencja buntu Adalberona I (zm. 1039), margrafa Styrii (1011-1035), przeciw Konradowi II. Pokonany w czerwcu 1035 r. Adalberon I wraz ze swym synem został wygnany z Karantanii. W miejsce Wielkiej Karanta-

30 Literatura związana z chrztem Karantan i zagadnieniami towarzyszącymi jest bogata, por. B. Grafenauer, Zgodovina, t. 2, s. 26-33; W. Kowalenko, Conversio Bagoariorum et Carantanorum, SSS I, s. 275-276. Autorstwo zabytku - abp Salzburga Adalwin (zm. 873), gdzie rozdziały 3-13 dotyczą zwłaszcza Karantan; V. Frančić, Boruta, s. 151; G. Labuda, Chotimir, s. 257-258; H. Wolfram, Conversio Bagoariorum et Carantanorum. Das Weißbuch der Salzburger Kirche über die erfolgreiche Mission in Karantanien und Pannonien, Wien 1979; Conversio Bagoariorum et Carantanorum. Das Weißbuch der Salzburger Kirche über die erfolgreiche Mission in Karantanien und Pannonien. Herausgegeben, übersetzt, kommentiert und um die Epistola Theotmari wie um Gesammelte Schriften zum Thema ergänzt, zweite, gründlich überarbeitete Auflage von H. Wolfram, Ljubljana/Laibach 2012.

31 B. Grafenauer, Zgodovina, t. 2, s. 58-61. 
nii pojawiła się Wielka Kraina złożona z trzech marchii: Krainy, Sawinji oraz Istrii. Na czele tego nowego tworu terytorialnego stanął margraf Ulryk I (1054-1070) i około 1063 r. zajął północne części królestwa chorwackiego leżące od Rašy do Senja (mian. Senj) oraz trzy wyspy: Osor, Cres, Krk. Dzięki tym podbojom utworzył Marchię Dalmatyńską. Po jego śmierci marchię zajął książę Slawonii - Zvonimir, który wnet został banem chorwackim. Rodzina Eppensteinów objęła tron książęcy w 1077 r., w zamian za poparcie Henryka IV w sporze o inwestyturę. Po nich, w 1122 r. władzę w Karantanii objęli członkowie rodu Spannheim, aż dynastia ta wygasła w 1269 r. na Ulryku III. To zaś bezpośrednio wpłynęło na rozwój stołecznego Celovca (Klagenfurt).

Niebezpieczeństwo awarskie w VII w. wplątało Karantan w związki z Bawarami, ci zaś naciskali na chrzest. Niechęć elit - może i innych grup - do nowej religii nie przyczyniła się do ściślejszych związków z Bawarami, od których jednak płynęły wskazówki dotyczące funkcjonowania państwa. Ale osłabienie Bawarów w starciu z Frankami przyniosło też skutki dla Karantan, którzy weszli w bezpośrednią zależność od Franków, którzy po 820 r. sprawili bawarskimi rękoma, że Słowianie byli stopniowo odsuwani od sprawowania władzy. Dotyczyło to zarówno rodziny książęcej, jak i żupanów, grup możnych. T. Wasilewski nie wykluczał celowej eksterminacji elit słowiańskich albo ich germanizacji. Jeśli nastąpiło to ostatnie, to więzy łączące zgermanizowanych Karantan z własną przeszłością oraz zwyczajami przodków musiały ulegać z pokolenie na pokolenie coraz bardziej znacznemu osłabieniu.

Znany słowiański obyczaj intronizacji książąt karantańskich, już istniejący w VIII w., stał się historycznym zwyczajem bez większego znaczenia, zamieniając się w ceremoniał hołdowniczy od schyłku XII w. Może rację miał uczony słoweński Bogo Grafenauer (1916-1995), dopatrując się w rodzimej tradycji „intronizacji książąt karynckich". Tym samym dystansował się do starszych teorii traktujących ten zwyczaj jako „osobliwość historyczną" ${ }^{32}$. Jak ten zwyczaj wyglądał jeszcze w IX w.? Otóż wyboru księcia karynckiego dokonywała grupa o nazwie kosezi wywodząca się z wolnych chłopów jednocześnie należąca do półszlachty. Byli oni wyznaczani przez lokalne zgromadzenia sądowe i udawali się na wiec. Zgromadzeniu wiecowemu przewodził wybrany sędzia ziemski, który przyjmował zgłoszenia kandydatów wskazanych przez królów niemieckich. Kandydaturę przyjmowano pozytywnie lub

32 S. Roman, Intronizacja ksią̇ąt karanckich, SSS, II, s. 285-286; tenże, Der kärntnerische Pfalzgraf, Südostforschungen 15 (1956), s. 108-123; B. Grafenauer, Ustoličenija koroškich vojvod in država karantanskich Slovencov, t. 1, Ljubljana 1952; P. Boroń, Kniaziowie, królowie, carowie... Tytuly i nazwy władców stowiańskich we wczesnym średniowieczu, Katowice 2010. 
ją odrzucano. Gdy wybór uznano za dokonany, przystępowano do intronizacji przy „Książęcym Kamieniu” nieopodal kościoła Panny Marii na Gosposvetskim Polu pod Kranskim Gradem. Wówczas gromadzili się nie tylko kozesi. Książę przywdziewał strój kozesa tj. - szare spodnie, takiż serdak z długimi rękawami, zakładał czerwoną torbę oraz pas, szary kapelusz, czerwone, sznurowane, wiejskie obuwie. Był to strój słowiańskich górali z Alp, nawiązujący do odzienia górali z Karpat, a precyzyjniej z gór bałkańskich. Wybrańca sadowiono na koniu i po trzykroć oprowadzano wokół wspomnianego kamienia, a towarzyszył temu śpiew zgromadzonych. Siedzący na tronie „sędzia ziemski” zwalniał mu miejsce po wymianie zdań z księciem i za symboliczny wykup składający się z kobyły, byka i monety. Kiedy książę zasiadł na tronie odbywała się proklamacja nowego władcy Karantanii przez „sędziego ziemskiego”.

Natomiast w drugiej połowie XII w. zasadniczą zmianą była likwidacja instytucji wiecu kozesów, a desygnowany uprzednio książę otrzymywał wcześniej nominację przed intronizacją. Ceremonii przewodził „sędzia ziemski”, który nie był już wybierany przez kozesów, lecz wskazywany, być może przez nominującego feudała lub nawet przez nowego księcia. Są to tylko hipotezy. Zatem zgromadzenie kozesów $\mathrm{w}$ czasie intronizacji miało charakter hołdu składanego przed nowym księciem. W XIII w. rola „sędziego ziemskiego” przypadła „książęcemu kmieciowi” z rodziny Blažni Vesi w pobliżu Celovca (Klagenfurt). Tradycja ta została uświęcona w $1414 \mathrm{r}$. i była żywa do 1822 r. ${ }^{33}$ Można zapytać, czego świadectwem była intronizacja książąt karantańskich. B. Grafenauer i inni badacze, zwłaszcza w XX w., przypuszczali, że była to „pamiątka” pochodząca z czasów jeszcze przed zetknięciem z Bawarami w latach czterdziestych VIII w., kiedy książę opierał się na drużynie, a ją tworzyli właśnie kozesi. Zdaje się, że zwierzchnictwo zrazu bawarskie, następnie frankijskie początkowo rażąco nie naruszały dotychczasowych obyczajów, które być może nie były tak sztywne, jak to sobie wyobrażamy. Należy pamiętać, że w IX-X w. doszedł obowiązek hołdu przed władcą frankijskim, co zmodyfikowało dawny porządek, a ceremoniał uległ pewnej petryfikacji. Także wprowadzenie chrześcijaństwa musiało odcisnąć swoje piętno, choćby przez dodanie elementu sakralizującego nowego księcia. Intronizacja władców karantańskich była także przejawem działań typowych dla ludów żyjących w środowiskach odosobnionych, takich jak góry. Silnie zakorzeniony separatyzm karantańskich Słowian wobec czyjegokolwiek zwierzchnictwa być może skutecznie wytworzony w VII w. - nakazywał podchodzić z rezerwą lub

33 S. Roman, Intronizacja, s. 285-286; T. Wasilewski, Historia Jugosławii, Wrocław-Warszawa-Kraków-Gdańsk-Łódź 1985, s. 37-38. 
wykazywać ciągoty do osłabiania powiązań ze środowiskami zewnętrznymi. Kiedy te więzy stały się faktem od lat czterdziestych VIII w., kozesi mogli wywierać wpływ na króla frankijskiego - akceptując bądź nie - jego desygnata ${ }^{34}$. Przez to mogli naciskać na władcę, aby ten przyjął ich postulaty np. w postaci przywilejów. Kiedy natomiast wiec kozesów w drugiej połowie XII w. stał się właściwie atrapą dawnych wyborów, automatycznie ich rola straciła na jakimkolwiek znaczeniu politycznym. Potwierdził to cesarz Fryderyk III Habsburg w 1443 r., który zabronił intronizacji, co stany Karyntii przyjęły z niezadowoleniem. Obok kozesów ważnymi grupami byli możni oraz żupani, resztę społeczności uzupełniali „ludzie wolni” i chłopi o statusie różnego stopnia zależności feudalnej. Ci pierwsi, pozycję ugruntowaną posiadali dzięki majątkom dziedzicznym (hereditas) wraz z ludźmi niewolnymi. Jednak o czasach do drugiej połowy VIII w. nie można nic pewnego powiedzieć. Później, kiedy karantańscy możni weszli w kontakty z Bawarami i Frankami, nawiązywali $\mathrm{z}$ nimi kontakty rodzinne. Prawdopodobnie $\mathrm{z}$ tego powodu zaczęli ulegać procesom asymilacyjnym, które skutkowały wtapianiem się w niekarantański żywioł i najzwyczajniej tracili kontakt z dotychczasową tożsamością. A jak przypuszczał T. Wasilewski, ulegali „wynarodowieniu” też z takiej racji, gdyż było ich stosunkowo niewielu. Pozyskiwanie ziemi przez możnych odbywało się przez wykup jej w okresach klęsk elementarnych, np. głodu. Handel ludnością niewolną był także atrakcyjną formą zysków. Niewolników sprzedawano w portach dalmatyńskich, choć nie była to forma specjalnie akceptowana, gdy Karantanię schrystianizowano.

Sytuacja możnych karantańskich zaczęła ewoluować w XI-XII w., kiedy już nie było można było pozyskiwać nowych terenów, a rentę odrobkową zamieniano na naturalną, aż wreszcie pieniężną ${ }^{35}$. Żupani na ziemiach Karantanii wywodzili się z dawnej starszyzny rodowej, która z małymi wyjątkami przekształcała się w grupę zawiadującą wspólnotami wiejskimi od IX-XII w., a pierwszy znany żupan Physso jest datowany na rok $777^{36}$. Grupa ta uformowała się i funkcjonowała odmiennie od np. żupanów chorwackich, właściwie nie odgrywając roli politycznej, jak działo się to w Chorwacji. Żupani byli uprzywilejowaną warstwą chłopów, która dysponowała dwułanowymi gospodarstwami, tzw. żupnicami. Obciążenia podatkowe, które na nich spoczywały, były mniej dotkliwe od tych nękających szeregowe chłopstwo.

\footnotetext{
34 B. Grafenauer, Zgodovina, t. 1, s. 143-149.

35 T. Wasilewski, Możni. Ziemie dzis. Jugosławii, SSS, III, s. 318-320.

36 H. Łowmiański, Geneza państw słowiańskich, [w: ] Studia nad dziejami Słowiańszczyzny, Polski i Rusi w wiekach średnich, Poznań 1986, s. 76.
} 
Byli oni zwolnieni z opłat fiskalnych lub płacili je w mniejszym stopniu, w wymiarze podatku z połowy gospodarstwa, ale tylko w postaci bydła, a nie zbóż. Żupani byli reprezentowani do czasów kolonizacji niemieckiej w XIII w. ${ }^{37}$ Osobną grupą byli już wzmiankowani kosezi, również będący, jak żupani, pewnym reliktem słowiańskim z czasów początków słowiańskiej Karantanii. Wywodzili się z grupy wojowników, być może drużyn książęcych. Po degradacji w procesie intronizacji książąt karantańskich od XIII w. obsadzali miejsce pomiędzy wolną ludnością wiejską a niemieckimi możnymi. Posiadali własne prawa, jurysdykcję i na nich spoczywał obowiązek służby wojskowej na rzecz księcia. W XI i XII w. ewoluowali oni w grupę rycerską. Tutaj należy podkreślić, że wśród nich sporadycznie pojawiały się osoby ze słowiańskimi imionami.

Obok wymienionych grup istniała najliczniejsza, choć niemożliwa do oszacowania, grupa ludności zwana „ludźmi wolnymi”, która przetrwała do X-XI w. Odróżniała się ona tym od Bawarów, że korzystała ze swych słowiańskich praw. Jednak i to uległo po XI w. zmianie, gdy „ludzie wolni” przekształcili się w zależnych kmieci.

Automatycznie dawne prawa słowiańskie przestały odgrywać jakąkolwiek rolę, teraz zmienione na prawa niemieckie. Tym samym Słowianie ulegali jurysdykcyjnie, politycznie, przewadze żywiołu frankijskiego, później niemieckiego, coraz bardziej zatracając swą kulturę rolną - i nie tylko - przyniesioną na te ziemie. Działo się to również pod wpływem zaniku mało wydajnych, dawnych, słowiańskich technik uprawy ziemi, zastępowanych wówczas nowinkami pochodzącymi ze świata niesłowiańskiego. W IX-X w. zupełnie zanikła technika wypaleniskowa, którą zastąpiono uprawą trójpolową. Tak zrodziła się na terytoriach słowiańskich uprawa łanowa, za którą odpowiedzieli byli poszczególni użytkownicy, nie zaś cała wspólnota, w gestii której pozostały jedynie łąki oraz lasy. Pomysł kolonizacji na prawie niemieckim przełożył się również na zmiany dotyczące gęstości zaludnienia, czyli nastąpił wzrost demograficzny ludności wiejskiej ${ }^{38}$.

Bodaj najliczniejszą grupą wśród Karantanan byli tzw. niewolni (servi), zobowiązani do dostarczania przychodów z renty odrobkowej, a później renty pieniężnej. Ich warunki bytowania były najsłabsze, biorąc pod uwagę grupy zamożniejsze. Do tego dochodzą dwa ważne dla Słowian postanowienia. Pierwsze z nich to rozwiązanie Karola Wielkiego z 791 r., który w nadaniu dla opactwa Kermsmünster narzucał obo-

37 J. Gurden, Slovenski župani v preteklosti, Ljubljana 1916; T. Wasilewski, Żupan, SSS, VII, s. 270; tenże, Możni, s. 318-320.

38 B. Grafenauer, Zgodovina, t. 2, s. 86-96. 
wiązek daniny na rzecz Kościoła, a kto tego nie chciał spełnić, był zmuszony opuścić terytoria należące do opactwa. Druga decyzja dotyczyła kolonizacji na prawie niemieckim, która od XIII w. torowała sobie drogę. Tereny dotąd zajęte przez Karantan, były teraz podporządkowane gospodarczo Bawarom, którzy przesuwali się w kierunku wschodnim oraz południowo-wschodnim. Karczowanie lasów, czego dokonywali Bawarzy, odbywało się jedynie w dolinach rzek, a to przyczyniało się do coraz mniejszych możliwości ekspansji Słowian. Osady karantańskie zaczęły zanikać, tak że w końcu XIII w. zupełnie ich nie było. Ludność słowiańska, opuszczając dotąd zajmowane ziemie, próbowała egzystować w lasach lub pośród terenów górzystych. Warunki życia przyczyniały się do jej powolnego przeradzania się w najsłabszą grupę pod względem ekonomicznym. Kolonizacja - która objęła m.in. Kotlinę Celowicką, Kotlinę Gradacką w Górnej Styrii, dolinę rzeki Murica, Dravsko Pole w Krainie i Dolnej Styrii - wpłynęła na umniejszenie roli politycznej Słowian karantańskich, ale także na położenie ludności chłopskiej, której było proporcjonalnie najwięcej. Chłopi niewolni zamieszkujący osady (municypia) byli całkowicie zależni od swych panów i winni byli świadczyć rentę odrobkową (tlaka) ${ }^{39}$. Chłopi półwolni (prazniki) byli obarczeni rentą naturalną, nadto nie mogli swobodnie opuścić miejsca zamieszkania i pracy. Natomiast posiadali oni prawo do własności ziemi, którą indywidualnie się zajmowali.

Oprócz powinności świeckich, które spadały na Karantan, należy pamiętać o zobowiązaniach nakładanych przez Kościól. Były to tzw. „słowiańska dziesięcina”, początkowo mniejsza dla Karantan niż Bawarów, a od połowy XI w. została ona zrównana do wielkości, którą płacili Niemcy. Oznaczać to może, że zdawano sobie sprawę z ograniczonych możliwości ekonomicznych Karantan, których w związku z tym traktowano w początkowym okresie ulgowo. Gdy osiągnęli oni wyższy próg dochodów, płacili tyle, ile Bawarzy. Kościół katolicki dbał o kontakt z Karantanami przez prowadzenie działalności misyjnej w języku słowiańskim i przyczynił się do popularyzacji pisma tekstów religijnych, dostosowując alfabet łaciński do potrzeb języka słowiańskiego. Stało się około roku 1000 (zabytki brižinskie lub fryzyńskie). Ale była to polityka prowadzona na krótką metę, gdyż po utwierdzeniu chrześcijaństwa wśród Karantan uznano za zbędne dalsze prace nad adaptacją tekstów łacińskich na język Słowian ${ }^{40}$. Tolerowano pieśni religijne śpiewane w języku słowiańskim, nie niszczono także trącących czasami pogańskimi zwyczajów „dożynkowych” wśród rolników słowiańskich.

39 B. Grafenauer, Zgodovina, t. 2, s. 137-144, bardzo szczegółowe ustalenia.

40 Tamże, t. 2, s. 109, 132-136. 
Właściwie trudno mówić o w pełni zachowanych obiektach architektonicznych ze słowiańskiej Karantanii z czasów architektury preromańskiej. Prawdopodobnie pierwsze obiekty powstały dopiero w czasach chrześcijańskich, ale i one zostały zniszczone przez najazdy węgierskie. Zachowały się resztki kościoła z czasów Karola Wielkiego w Kranskim Gradzie i kilka fragmentów obiektów na terenie całej Karantanii. Natomiast w czasach romańskich budowli powstało znacznie więcej (źródła mówią o 160 obiektach), ale równie niewiele zachowało się do późniejszych czasów. Zresztą, czy jest jakiś udział przy ich fundacjach Karantan, nie wiadomo. Były to kościoły, opactwa, budynki świeckie, zamki etc., a ich fundatorami byli bawarscy możni lub arcybiskupi Salzburga, rody książęce Spanheimów, Eppensteinów oraz Višnjegorskich.

Widoczne były skutki rozwoju kolonizacji bawarskiej, która odbierała Słowianom ziemie i lasy dotąd przez nich zajmowane. Wskutek naporu żywiołu bawarskiego Słowianie ustępowali w dolinach rzek, wypierani w okolice podgórskie i górskie. Karantanie ze względów zapewne demograficznych i mniejszego rozwoju cywilizacyjnego na tle np. Bawarów, pomimo prób zachowania niezależności, okazali się żywiołem nie na tyle silnym, aby dalej opierać się plemionom dominującym (Frankowie, Bawarzy).

Nie można powiedzieć, że kultura Słowian karantańskich przetrwała dłuższy czas po przyjęciu chrztu i powolnym wmontowywaniu Karantan w świat zachodni. Wpłynęły na to takie elementy, jak procesy adaptacyjne po chrystianizacji oraz polityczna zwierzchność Bawarów i Franków nad Karantanami. Te dwa czynniki skutecznie przyczyniły się do eliminowania słowiańskiej kultury karantańskiej. B. Grafenauer zauważa, że decydujący wpływ na krzewienie kultury frankijskiej miał Kościół i intensywna, rozpoczęta na początku IX w. akcja chrystianizacyjna. Frankowie przyczynili się do napływu Bawarów na początku IX w., a ci z kolei mozolnie budowali struktury kościelne, od parafii poczynając. Sprzyjało temu podporządkowanie organizacji kościelnej Salzburgowi, tym samym likwidujące wskazanie Karola Wielkiego, który opowiadał się za przyznaniem prymatu arcybiskupstwu Akwilei. Ta zaś nie wykazywała takiej dynamiki misyjnej jak Salzburg. Aktywne misje trwały również we wschodnich połaciach Karantanii, która powoli integrowała się z pozostałymi terenami. Było to spowodowane tym, że misjonarze nie posługiwali się w swej pracy językiem słowiańskim. Kościół natomiast znalazł silne oparcie w możnowładztwie karantańskim. Szło to w parze z budowaniem porządku feudalnego i sprzężeniu go 
z polityką kościelną. Kościół stawał się elementem budującym jedność wśród Karantan, chętnie współdziałały z nim najbardziej wpływowe grupy. Jednak na początku X w. biskupi bawarscy zdali sobie sprawę z zaniku religii chrześcijańskiej wśród Karantan. Kościół jednak zaproponował nową jakość w Karantanii - ale znaną już wcześniej z innych ziem - skupiając w klasztorach i miastach ośrodki mogące zaświadczać o swej ekspansji religijnej oraz kulturalnej. Jedynym bodaj orężem schrystianizowanych uboższych Karantan stał się od X w. język, którym się posługiwali. W XI w. Kościół przystąpił do propagowania psalmów w języku Karantan. Dostosował on także alfabet łaciński do języka słowiańskiego i czynił wysiłki, aby utrwalić modlitwy, formuły religijne w takim zapisie. Te zachęty okazały się skuteczne, jeśli chodzi o ludność miejską, natomiast w środowiskach wiejskich bądź pasterskich taka polityka okazywała się nieprzydatna. Z chwilą gdy hierarchia kościelna uznała, że proces chrystianizacji został w Karantanii zakończony w X i XI w., wysiłki translatorskie ustały. Jak podkreślają słoweńscy badacze, kultura karantańska przetrwała dzięki folklorowi, poezji ludowej, balladom, piosenkom, opierając się wpływom rodzimych elit i samego Kościoła. Przykładem tu może być pieśń „Lepa Vide” mająca różne zakończenia, a wywodząca się z kręgu bizantyńskiego z VII-VIII w., która dotarła do Karantan około IX/X w. ${ }^{41}$

Najdawniejsze zabytki piśmiennictwa karantańskiego pochodzącą z około $1000 \mathrm{r}$. Są to dwa formularze spowiedzi oraz towarzyszące im teksty o grzechu i pokucie. Jako że teksty są znane z kodeksu ówczesnego biskupa Fryzyngii (Freising), zwane są zabytkami fryzyńskimi zapisanymi z języku słoweńskim-brižinskim. Oprócz tego mamy pieśni kościelne, tzw. „kirielejsona” również po słoweńsku, oraz utwory będące nawiązaniem do tradycji pasterskich Karantan i być może pochodzące z okresu przed przyjęciem chrztu. Na tym właściwie kończą się karantańskie ślady twórczości literackiej z okresu IX-XI w.

Nie miały szczęścia dotrwać do czasów współczesnych zabytki architektury z epoki preromańskiej. Walnie przyczynił się do tego najazd węgierski. Zachowały się tylko fragmenty ruin budowli z czasów Karola Wielkiego w Kranskim Gradzie, rzeźby kamienne z ornamentyką trójwstęgową ze Sliwnicy nieopodal Mariboru i jeszcze dwa reliefy, wykonane nieporadnymi rękoma w Hodišach i w kościele św. Jerzego na Svetich Gorach. Z okresu romańskiego zachowało się równie niewiele pamiątek architektury, choć ówczesne źródła wyliczają, jak wspomniano, aż 160 za-

41 Tamże, t. 2, s. 26-33; I. Grafenauer, Lepa Vida. Študija o izvoru, razvoju in razkroju narodne balade o Lepi Vidi, Ljubljana 1943; I.A. Nabergoj, Hrepenenje in skušnjava v svetu literature. Motiv Lepe Vide, Ljubljana 2010. 
bytków. Dotrwały tylko te, które miały charakter monumentalny, jak np. kościól św. Pawła zbudowany przez benedyktynów w Labodnicy i opactwo cysterskie w Stičnej. Ale te budowle były wzorowane na obcych, niekarantańskich wzorcach, których nie znamy, albo których nie było. Natomiast w Istrii budowle były odzwierciedleniem budownictwa dalmatyńskiego będącego pod silnym wpływem wzorów weneckich.

Z czego mógł wynikać ten stan rzeczy? Najprawdopodobniej było to spowodowane „słabymi fundamentami społeczeństwa” karantańskiego (B. Grafenauer), gdy wzrastała pozycja Kościoła przeżywającego okres odradzania się i świetności. Architektura ma zatem charakter kolonialny na tych ziemiach, nie wynika z własnej drogi rozwojowej Słowian, lecz przymusowej akceptacji narzucanych wzorców. Bogo Grafenauer widział połączenie idei Kościoła wraz z władzą świecką, które skutecznie utemperowały Karantan i naprowadziły na swoje tory rozwojowe. Obie siły, przejściowo obce i być może niezrozumiałe dla Słowian Alpejskich przyczyniły się do pohamowania tego, co było w kulturze Karantan z czasów pogańskich. W Karantanii odniosły sukces wyższe, zrazu frankijska, łacińska, a następnie germańska i śladowo, włoska kultury ${ }^{42}$.

Historia Karantan pokazuje, jak trudno było próbować zbudować w środkowo-południowej Europie przyczółek słowiański. Karantanie musieli liczyć się z ingerencją sąsiadów, naciskami religijnymi, ideologicznymi oraz różnymi wpływami. Wyraźnie widać, że polityczną i zapewne demograficzną słabość żywiołu Karantan, bezwzględnie wykorzystały ośrodki zbudowane na innych, trwalszych fundamentach politycznych i religijnych, posiadające również prominentnych władców. Nie można także zapominać, że czas formowania się państwa karantańskiego to w ówczesnej Europie okres trwających jeszcze fal migracji. Miało to również wpływ na szukających swego miejsca Karantan.

\section{Bibliografia}

\section{Źródła}

Itineraria Romana, Bd. II: Ravennatis Anonymi cosmographia et Guidonos geographica, ed. J. Schnetz, Leipzig 1929 i nowe wydanie 1990.

Paweł Diakon, Historia Longobardów, przełożył, wstępem i komentarzem opatrzył I. Lewandowski, Warszawa 1995. 
Gradivo za zgodovino Slovencev v srednjem veku, zbral F. Kos, t. 1-4 i t. 5, uredil M. Kos, Ljubjana 1902-1928, https://www.dlib.si/details/URN:NB$\mathrm{N}: S I: D O C-2 J X M K E I W$.

\section{Literatura}

Bezlaj F., Etimološki slovar slovenskega jezika, Vol. 2: K-O, red. B. Gerlanc, Ljubljana 1982.

Boroń P., Kniaziowie, królowie, carowie... Tytuły i nazwy władców słowiańskich we wczesnym średniowieczu, Katowice 2010.

Bratož R., Slovenija in sosednje dežele med antiko in karolinško dobo, začetki slovenske etnogeneze, Ljubljana 2000.

Čepič Z. et al., Zgodovina Slovencev, Ljubljana 1979.

Chrzanowski W., Świętopetk I Wielki król wielkomorawski (ok. 844-894), Kraków 2008. Conversio Bagoariorum et Carantanorum. Das Weißbuch der Salzburger Kirche über die erfolgreiche Mission in Karantanien und Pannonien. Herausgegeben, übersetzt, kommentiert und um die Epistola Theotmari wie um Gesammelte Schriften zum Thema ergänzt, zweite, gründlich überarbeitete Auflage von $\mathrm{H}$. Wolfram, Ljubljana/ Laibach 2012.

Dopsch H., Das Erzbistum Salzburg und der Alpen-Adria-Raum im Frühmittelalter unter besonderer Berücksichtigung des Salzburger Slawenmission, [w:] Karantanien und der Alpen, s. 101-150.

Frančić V., Boruta, SSS, I, s. 151.

Gleirscher P., Karantanien - das slawische Kärnten, Klagenfurt 2000.

Grafenauer B., Ustoličenija koroškich vojvod in država karantanskich Slovencov, t. 1, Ljubljana 1952.

Grafenauer B., Zgodovina slovenskega naroda, t. 1-3, Ljubljana 1954-1961.

Grafenauer I., Lepa Vida. Študija o izvoru, razvoju in razkroju narodne balade o Lepi Vidi, Ljubljana 1943.

Gurden J., Slovenski župani v preteklosti, Ljubljana 1916.

Habijan V., Mejniki slovenske zgodovine, Ljubljana 1997.

Hurbanič M., The Avar Siege of Constantinople in 626: History and Legend, London-New York 2019.

Kahl H.D., Das Fürstentum Karantanien und die Anfänge seiner Christianisierung, [w: ] Karantanien und der Alpen, s. 37-99.

Kahl H.D., Der Staat der Karantanen. Fakten, Thesen und Fragen zu einer frühen slawischen Machtbildung im Ostalpenraum (7.-9. Jh.), Ljubljana 2002. 
Karantanien - Mutter von Kärnten und Steiermark, Hrsg. W.R. Baier, Klagenfurt 2003. Karantanien und der Alpen-Adria-Raum im Frühmittelalter, Hrsg. G. Hödl, J. Grabmayer, Wien 1993.

Korošec P., Alpski Slovani, Ljubljana 1990.

Kos M., Conversio Bagoariorum et Carantanorum, Ljubljana 1936.

Kos M., Zgodovina Slovencev od naselitve do reformacije, Ljubljana 1933.

Kowalenko W., Conversio Bagoariorum et Carantanorum, SSS I, s. 275-276.

Kowalenko W., Ljudevit, SSS, III, s. 85-86.

Kuryłowicz J., Karyntia, SSS, t. II, s. 381.

Labuda G., Chotimir, SSS, I, s. 257-258.

Labuda G., Kakacjusz, SSS, II, s. 351-352.

Lehr-Spławiński T., Kocelj, SSS, II, s. 435.

Leśny J., Tassilo III, SSS, VI, s. 33.

Łowmiański H., Geneza państw stowiańskich, [w:] Studia nad dziejami Stowiańszczyzny, Polski i Rusi w wiekach średnich, Poznań 1986.

Mühle E., Die Slawen im Mittelalter zwischen Idee und Wirklichkeit, Köln 2020.

Mühle E., Die Slawen, München 2017.

Nabergoj I.A., Hrepenenje in skušnjava v svetu literature. Motiv Lepe Vide, Ljubljana 2010.

Nalepa J., Bawaria, SSS, I, s. 95-97.

Ovsec D.J., Slovanska mitologija in verovanje, Ljubljana 1991.

Pentek Z., Chrystianizacja Stowian Południowych, [w:] Chrystianizacja „Młodszej Europy”, red. J. Dobosz, J. Strzelczyk, M. Matla, Poznań 2016, s. 137-146.

Roman S., Der kärntnerische Pfalzgraf, Südostforschungen 15 (1956), s. 108-123.

Roman S., Intronizacja książąt karanckich, SSS, II, s. 285-286.

Sieklicki J., Pribina, SSS, IV, s. 346-347.

Skowronek J., Tanty M., Wasilewski T., Historia Stowian potudniowych i zachodnich, Warszawa 1988.

Štih P., Glossen zu einer neuen Monographie über Karantanien, Carinthia (2006), s. 99-126.

Štih P., Karantanci - zgodnjesrednjeveško ljudstvo med Vzhodom in Zahodom, Zgodovinski časopis 61 (2007), s. 47-58.

Štih P., Ozemlje Slovenije v zgodnjem srednjem veku, osnovne poteze zgodovinskega razvoja od začetka 6. stoletja do konca 9. stoletja, Ljubljana 2001.

Štih P., Regnum Carantanum, Zgodovinski časopis 40 (1986), št. 3, s. 215-231.

Störmer W., Tassilo III, Mittelalterische Lexikon, t. IV, col. 485-486. 
Strzelczyk J., Iroszkoci w kulturze średniowiecznej Europy, Warszawa 1987.

Strzelczyk J., Mapy, SSS, III, s. 164.

Strzelczyk J., Od Prastowian do Polaków, Kraków 1987.

Swoboda W., Stowianie w Alpach, SSS, V, s. 285-288.

Swoboda W., Walluk, SSS, VI, s. 300-301.

Swoboda W., Waltunk, SSS, VI, s. 303.

Wasilewski T., Feudalizm w Stowenii, SSS, II, s. 48-49.

Wasilewski T., Historia Jugosławii, Wrocław-Warszawa-Kraków-Gdańsk-Łódź 1985.

Wasilewski T., Możni. Ziemie dzis. Jugosławii, SSS, III, s. 318-320.

Wasilewski T., Żupan, SSS, VII, s. 270.

Wolfram H., Conversio Bagoariorum et Carantanorum. Das Weißbuch der Salzburger Kirche über die erfolgreiche Mission in Karantanien und Pannonien, Wien 1979.

Wolfram H., Der Zeitpunkt der Einführung der Grafschaftsverfassung in Karantanien, Veröffentlichungen des Steiermärkischen Landesarchivs 12 (1981), s. 313-317. Wolfram H., Karantanija med vzhodom in zahodom. Obri, Bavarci in Langobardi v 8. in 9. stoletju, Zgodvinski Casopis 45 (1991), s. 177-187.

Wolfram H., Privina, Fürst in Pannonien (830/40/+ um 860), Lexikon des Mittelalters, Bd. 7, München 1995.

Wolfram H., Salzburg, Bayern, Österreich. Die Conversio Bagoariorum et Carantanorum und die Quellen ihrer Zeit, Wien-München 1995.

\section{Summary}

\section{Carantans - Alpine Slavs from the $6^{\text {th }}$ to the $15^{\text {th }}$ century}

The article is devoted to the history of one of the South Slavic tribes - Carantans. They are also called Alpine Slavs. The source documents about the Carantans date back to the $7^{\text {th }}-8^{\text {th }}$ centuries. Then they occupied the Carnic Alps and interacted with neighboring tribes, such as the Bavarians. An important qualitative change for the Carantans was baptism in the middle of the $8^{\text {th }}$ century, and since then ecclesiastical institutions began to operate. Around 820, the Franks stopped the nascent Slavic feudalism, making Carantania a county (March of Carinthia). After the uprising of Ljudevit in 823, the Franks strengthened their reign over the Carantans. Conversio Bagoariorum et Carantanorum from the reign of $d u x$ Kocel in 870 or 871 was also presented. In 1122, the Spannheim family ruled over Carantania until its end in 1269. 
Nadesłany: 13 III 2021

Nadesłany po poprawkach: 7 VIII 2021

Zaakceptowany: 17 IX 2021

Dr hab. Zdzisław Pentek, prof. UAM

Uniwersytet im. Adama Mickiewicza w Poznaniu

Wydział Historii

ul. Uniwersytetu Poznańskiego 7

61-614 Poznań

e-mail: zp26@amu.edu.pl 